(RESEARCH ARTICLE)

\title{
Physicochemical properties of cassava (Manihot esculenta) tapai fermented by aeration
}

\author{
Erika Desta Ria 1, Priyanto Gatot 1,2, ${ }^{*}$, Wijaya Agus 1,2, Santoso Budi 1,2 and Pambayun Rindit 1,2 \\ ${ }^{1}$ Agroindustrial Technology Interest of Agribusines Magister Study Program, Faculty of Agriculture, Sriwijaya University, \\ Indonesia. \\ ${ }^{2}$ Departement of Agricultural Technology, Faculty of Agriculture, Sriwijaya University, Indonesia.
}

Publication history: Received on 12 December 2019; revised on 19 December 2019; accepted on 21 December 2019

Article DOI: https://doi.org/10.30574/wjarr.2019.4.2.0103

\begin{abstract}
The research was aimed to determine the physical and chemical properties of cassava tapai. Experiment was conducted on completely randomized factorial design, with two treatments, namely aeration treatment dan fermentation treatment. The measuring parameters was consisted of texture, chemical properties (moisture content, $\mathrm{pH}$, content of alcohol, amylose, reducing sugar and total acid) and sensory analysis (hedonic test). The result show that aeration treatment had a significant effect on texture, $\mathrm{pH}$, alcohol, amylose, and total acid content, and fermentation time had a significant effect on texture, moisture content, $\mathrm{pH}$, alcohol, amylose, and total acid content. The interaction between aeration treatment and fermentation time had a significant effect on $\mathrm{pH}$ and alcohol. Tapai with lowest alcohol content of 2.48 per cent was observed on aerated fermentation for 48 hours, which was signficantly lower than non-aerated tapai fermentation on the same time. The aeration system decreased significantly the tapai alcohol content compared to the system without aeration.
\end{abstract}

Keywords: Manihot esculenta; Tapai; Fermentation; Aeration

\section{Introduction}

Tapai is one of the original fermented foods found in Indonesia. There are two types of tapai, one made from cassava and the other is from sticky rice. Starch substances that are in food are converted into a simple form of sugar, with the help of a microorganism called yeast or yeast [1]. At least 10 types of microbes are involved in fermentation, which includes yeast (Saccharomyces cerevisiae, Candida krusei, Candida pelliculosa, Candida guillermondii, Candida magnolice and Rhizopus glutinis) and including lactic acid bacteria (LAB) (Lactobacillus brevis, LL) plantarum, L. collino, L. collino L. casei, and Pediococcus sp.)[2].

S. cerevisiae is an anaerobic facultative organism that can use both aerobic and anaerobic systems to obtain energy from glucose breakdown. . cerevisiae is a species that is fermentative in the process of fermentation, which breaks down glucose into $\mathrm{CO}_{2}$ and strong alcohol. But in the presence of oxygen, $S$. cerevisiae can also do respiration that is oxidizing sugar into $\mathrm{CO}_{2}$ and water [3].

Oxygen availability and strain compatibility are considered to have a large influence on the speed of fermentation because they have an impact on yeast metabolism and growth during fermentation [4]. S. cerevisiae during fermentation which utilizes most of the oxygen. The reduction of oxygen concentration creates anaerobic conditions in the fermentation media.

\footnotetext{
${ }^{*}$ Corresponding author

E-mail address: gpriyanto@unsri.ac.id
} 
The more fermentation time causes more alcohol to be produced from the results of yeast metabolites so that the aroma of alcohol is stronger and disliked [5].The main purpose of this study was to determine the effect of aeration on cassava tapai properties.

\section{Material and methods}

\subsection{Materials}

Main material was used ragi tapai and cassava. Ragi type was used usually known as white ragi from local industries and cassava (Manihot esculenta) usually known as white cassava obtained from local market at Palembang, Indonesia, in September 2019. The experiment and analysis was conducted at the Laboratory of Agricultural Product Chemistry, Faculty of Agriculture, Sriwijaya University, Indonesia.

\subsection{Design of Experiment}

Experiment was conducted on completely randomized factorial design, with two treatment, namely aeration treatment dan fermentation treatment. The aeration treatment was consisted of two level, namely no aeration treatment (without aeration, coded by A1) and by aeration coded by A2). The fermentation time was consisted of five level treatment, namely 0, 24, 48, 60, 72 and 96 hours (respectively coded by B1, B2, B3. B4, and B5).

\subsection{Sample Preparation}

Cassava is sorted, then peeled and cut. Cassava that has been cut and weighed as much as 0.5 grams steamed for \pm 30 minutes. After chilling to room temperature for 30 minutes. Cassava inoculated for as much as 1 gram of yeast. Cassava is put into a jar then closed tightly. Cassava is fermented at $30^{\circ} \mathrm{C}$ according to the treatment.

\subsection{The physical analysis}

The followings were the tools and equipment employed : Texture of the samples were determined by using Texture Analyzer type TA 17.Mounted Brook just above the sample. The needle is attached to the tip of the sample to be analyzed. The speed on the texture analyzer is set (trigger 5 grams, distance $5 \mathrm{~mm}$ and speed $5 \mathrm{~mm} / \mathrm{s}$ ). Blade type Brooke will press right in the middle of the sample. Then the display will display the value in units of gram force (gf) [6].

\subsection{The Chemical Analyis}

\subsubsection{Amylose content}

Sample $(100 \mathrm{~g})$ is added $1 \mathrm{~mL}$ of $95 \%$ ethanol and $9 \mathrm{~mL}$ of $\mathrm{NaOH} 1 \mathrm{~N}$. The sample is heated in boiling water for \pm 10 minutes at $100^{\circ} \mathrm{C}$ to form a gel. The gel is transferred into a $100 \mathrm{~mL}$ measuring flask, shaken and diluted with distilled water until the marks. The solution taken as much as $5 \mathrm{~mL}$ was transferred in a $100 \mathrm{~mL}$ measuring flask and $1 \mathrm{~mL}$ of 1 $\mathrm{N}$ acetic acid added and $2 \mathrm{~mL}$ of iodine solution.The solution is diluted to the mark with aquadest, shaken and allowed to stand for 20 minutes. Solutions that have changed color to blue are measured by a spectrophotometer with a wavelength of $625 \mathrm{~nm}$. The color obtained is matched with a standard curve and then the absorbance can be seen and the amylose content were calculated as the equation below [7].

$$
\text { Amylose content } \%=\frac{\text { Amylose concentration from the standard curve } \times \text { Final volume } \times \text { Dilution factor }}{\text { Sample weight }}
$$

\subsubsection{Total Acid Content}

Sample $(10 \mathrm{~g})$ of put into the beaker glass, added aquadest to a volume of $100 \mathrm{~mL}$ Stir until evenly distributed and filtered using filter paper. $10 \mathrm{ml}$ of filtrate is taken and put into erlenmeyer then $1 \%$ phenolphethalein drops, $2-3 \mathrm{drops}$. Then titrated using 0.1 $\mathrm{N} \mathrm{NaOH}$. Titration is stopped after pink is formed. Total acid were calculatedas the equation below [8].

$$
\text { Total acid }(\%)=\frac{\text { Volume of } \mathrm{NaOH} \times \mathrm{N} \mathrm{NaOH} \times \frac{100}{25} \times 90}{\text { Sample volume }(10 \mathrm{ml}) \times 1000} \times 100
$$




\subsubsection{Alcohol content}

Sample $(1 \mathrm{ml})$ and potassium carbonate solution $(1 \mathrm{ml})$ are added separately to the edge of the cup. $1 \mathrm{~mL}$ potassium bichromate solution is inserted in the center of the cup. And then, potassium bichromate solution (1ml) is inserted in the center of the cup. Cover the cup carefully and close it with vaseline. Shake slowly so that the saturated potassium carbonate sample and solution mix well. After mixing leave it for 1-2 hours and observe the color changes in the potassium bichromate acid sulfuric solution in the middle of the cup. The change in the color of potassium bichromate sulfuric acid from yellow to bluish green indicates the presence of ethanol in the sample tested. Taking a potassium bicarbonate solution with a micropipette, try all the solutions taken. Put in a $10 \mathrm{~mL}$ measuring flask and diluted to mark limits. Observed the absorbance using a spectrophotometer at $\lambda=480 \mathrm{~nm}$. Alcohol content were calculated as equation below [9].

Alcohol content $=$ solution of concentration concentration from the standard curve $\mathrm{x}$ dilution factor $\mathrm{x} \rho \mathrm{C}_{2} \mathrm{H}_{5} \mathrm{OH}(0.789)$

\subsubsection{Reducing Sugar Content}

Reagents of Nelson $1 \mathrm{~mL}$ is added to each measuring cylinder, and heated for 20 minutes. After chilling add $1 \mathrm{~mL}$ of Arsenomolybdat reagensia, stir until all the remaining CuSO4 deposits dissolve again. $7 \mathrm{~mL}$ of distilled water is added and stirred until homogeneous. The optical density (OD) is applied to each solution at a wavelength of $540 \mathrm{~nm}$. Reducing sugar content were calculated as the equation below [10].

$$
\text { Reducing sugar content }(\%)=\frac{\text { glucose concentration from the standard curve } \times \text { dilution factor }}{\text { sample weight }} \times 100
$$

\subsection{Statistical analysis}

All analyses were performed in triplicates. Results were expressed by means of \pm standard deviation. Statistical significance was established using Analysis of Variance (ANOVA) models to estimate the properties and parameters of cassava tapai. Means were separated according to Duncan's multiple range analysis $(\mathrm{p}<0.5)$, with the program asisted of SAS software (9.0 vertion). [11].

\section{Results and discussion}

The test results of texture values, amylose content, total acid content, alcohol content, and reducing sugar content in cassava tapai are shown in Table 1.

Table 1 Texture values, amylose content, total acid content, alcohol content, and reducing sugar content in cassava tapai

\begin{tabular}{llllll}
\hline Treatment & Texture (gf) & $\begin{array}{l}\text { Amylose } \\
\text { Content (\%) }\end{array}$ & $\begin{array}{l}\text { Total Acid } \\
\text { Content (\%) }\end{array}$ & $\begin{array}{l}\text { Alcohol } \\
\text { Content (\%) }\end{array}$ & $\begin{array}{l}\text { Reducing sugar } \\
\text { content (\%) }\end{array}$ \\
\hline A1B1 & $260.00 \pm 13.62^{\mathrm{a}}$ & $16.79 \pm 0.34^{\mathrm{a}}$ & $0.20 \pm 0.02^{\mathrm{g}}$ & $0.00 \pm 0.00^{\mathrm{a}}$ & $18.14 \pm 1.06^{\mathrm{a}}$ \\
A1B2 & $185.00 \pm 9.97^{\mathrm{c}}$ & $14.94 \pm 0.88^{\mathrm{bcd}}$ & $0.26 \pm 0.03^{\mathrm{g}}$ & $0.98 \pm 0.29^{\mathrm{a}}$ & $15.92 \pm 0.60^{\mathrm{b}}$ \\
A1B3 & $134.20 \pm 3.2^{\mathrm{e}}$ & $13.68 \pm 1.35^{\mathrm{de}}$ & $0.52 \pm 0.03^{\mathrm{d}}$ & $4.12 \pm 0.24^{\mathrm{d}}$ & $13.62 \pm 1.52^{\mathrm{d}}$ \\
A1B4 & $125.07 \pm 4.54^{\mathrm{ef}}$ & $12.53 \pm 0.60^{\mathrm{e}}$ & $0.67 \pm 0.04^{\mathrm{c}}$ & $5.77 \pm 0.29^{\mathrm{b}}$ & $12.38 \pm 0.78^{\mathrm{e}}$ \\
A1B5 & $114.93 \pm 4.30^{\mathrm{f}}$ & $12.18 \pm 0.60^{\mathrm{e}}$ & $0.88 \pm 0.04^{\mathrm{a}}$ & $6.89 \pm 0.40^{\mathrm{a}}$ & $5.17 \pm 0.47^{\mathrm{h}}$ \\
A2B1 & $260.33 \pm 5.30^{\mathrm{a}}$ & $16.24 \pm 0.54^{\mathrm{ab}}$ & $0.20 \pm 0.01^{\mathrm{g}}$ & $0.00 \pm 0.00^{\mathrm{a}}$ & $18.30 \pm 1.07^{\mathrm{a}}$ \\
A2B2 & $197.07 \pm 5.91^{\mathrm{b}}$ & $16.09 \pm 0.39^{\mathrm{abc}}$ & $0.25 \pm 0.01^{\mathrm{fg}}$ & $0.00 \pm 0.00^{\mathrm{a}}$ & $15.42 \pm 1.47^{\mathrm{bc}}$ \\
A2B3 & $173.80 \pm 0.91^{\mathrm{c}}$ & $15.24 \pm 1.30^{\mathrm{bc}}$ & $0.43 \pm 0.040^{\mathrm{e}}$ & $2.48 \pm 0.32^{\mathrm{e}}$ & $11.28 \pm 0.39^{\mathrm{c}}$ \\
A2B4 & $150.33 \pm 4.00^{\mathrm{d}}$ & $14.69 \pm 1.00^{\mathrm{cd}}$ & $0.54 \pm 0.03^{\mathrm{d}}$ & $4.02 \pm 0.25^{\mathrm{d}}$ & $7.26 \pm 0.95^{\mathrm{f}}$ \\
A2B5 & $136.53 \pm 5.17^{\mathrm{e}}$ & $12.98 \pm 0.52^{\mathrm{e}}$ & $0.77 \pm 0.17^{\mathrm{b}}$ & $4.88 \pm 0.09^{\mathrm{c}}$ & $14.52 \pm 0.28^{\mathrm{g}}$ \\
\hline
\end{tabular}

Values are means of triplicate measurement with standard deviation \pm

The treatment of A1 has a lower texture than the treatment of A2. During the fermentation process, organic acids and enzymes are produced to break down proteins and lipids so that large amounts of amylose are dissolved, so that the 
formation of stronger tissue structures leads to an increase in the hardness, chewiness of fermented products [12]. The treatment of B5 has a lower texture than the treatment of B1. Long fermentation in tapai cassava cause texture produced softer. Other than $\mathrm{CO}_{2}$ or energy on the process of fermentation in aerobic also produces $\mathrm{H}_{2} \mathrm{O}$ will be watery, tapai texture so the more long fermentation will produce tapai that is soft and watery [13].

The treatment of B5 has a lower texture than the treatment of B1. The difference in amylose in cassava is because during fermentation the yeast produces the extracellular enzyme amylase and protease, then the $\alpha$-amylase enzyme, in starch, is likely to carry out amylolysis, ie complete starch degradation and soon to become maltose and maltotriose. This amylolysis step is the result of the work of enzymes randomly cutting 1,4 glycoside glycosidic bonds, consequently, the amylose glycosidic straight chain becomes a short chain. Amylose content of fermented cassava starch is lower, namely $11.28 \%$ - $15.61 \%$ than the natural amylose starch of cassava starch (15.85\%). This is presumably because amylose is degraded by amylolytic enzymes (amylase) produced by yeast. Amylase will hydrolyze amylose to produce maltose and glucose. Furthermore, the glucose formed is consumed by yeast [14].

The treatment of A2 has a lower total acid than the treatment of A1. The difference in total acid in cassava is due to the influence of oxygen which oxidizes ethanol to lactic acid so that the $\mathrm{pH}$ will [15], so the total acid will increase. The treatment of B1 had lower total acid than the treatment of B5. This shows that the higher the concentration of lactic acid bacteria and the longer the fermentation time, the higher the total acid of the product. This is due to lactic acid bacteria (L. plantarum) fermenting sugar into lactic acid, so the longer the fermentation time, the lactic acid produced by the lactic acid bacteria is higher. Likewise, the higher concentration of lactic acid bacteria, the higher the total acid, because the growth of lactic acid bacteria increases so that the higher lactic acid produced [16].

The treatment of A2B5 has lower alcohol content than the A1B5 treatment. Oxygen indirectly affects the fermentation time carried out by S.cerevisiae. It could grow well under aerobic conditions, but to perform the process of alcohol fermentation, anaerobic conditions are needed [17]. S.cerevisiae grows well under aerobic conditions. In aerobic conditions Saccharomyces cerevisiae hydrolyzes sugar into water and $\mathrm{CO}_{2}$, but in anaerobic conditions the sugar will be converted by $S$. cerevisiae into alcohol and $\mathrm{CO}_{2}[3]$.

The treatment of B5 treatment has lower reducing sugar content than the treatment of B1. The fermentation process of cassava is started by changing the starch in cassava by the enzyme amylase released by microbes into maltose. Maltose can be converted into glucose by the enzyme maltase. Glucose by the enzyme zimase is converted into alcohol [18]. During fermentation, mold changes carbohydrates in degraded substrates into simple sugars and is converted to ethanol by microorganism activity so that the sugar contained in cassava starch decreases [19].

\section{Conclusion}

Fermented by aeration of tapai had a significant effect on the average values texture, chemical analysis of cassava tapai consists of amylose content, total acid content, alcohol content, and reducing sugar content of cassava tapai. The aeration system was successfully decrease the alcohol content compared to the system without aeration. The lowest alcohol content of 2.48 per cent was observed on aerated fermentation for 48 hours.

\section{Compliance with ethical standards}

\section{Acknowledgments}

We would like to express our gratitude to Sriwijaya University at Palembang Indonesia, which was supporting the financial aid for some part of the experiment, especially tools, main material and analysis.

\section{Disclosure of conflict of interest}

Author declare no conflict of interest exist.

\section{References}

[1] Hasanah H, Jannah A and dan Fasya AG. (2012). The Effect of Fermentation Time on Tapai Cassava Alcohol Content (Manihot utilissima Pohl). Alchemy, 2(1), 68-79.

[2] Chiang YW, Chye FY and Ismail M. (2006). Microbial Diversity and Proximate Composition of Tapai. Malay. J. Microbiol., 2(1), 1-6. 
[3] Kunaepah U. (2008). Effect of Fermentation Time and Glucose Concentration on Antibacterial Activity, Total Polyphenols and Chemical Quality of Red Bean Milk Kefir, Thesis. Diponegoro University, Semarang.

[4] Hansen EH, Nissen P, Sommer P, Nielsen P and Arnborg, N. (2001). The Prognosis After Surgical Treatment for Carcinoma of the Colon and rectum. Comparison of each 5 year Survival Rate in The Patients With Cancer of The Colon and Rectum. J. The Japan Soc. Colo Proct, 91, 541-547.

[5] Syahputri GA, Julianti E and Nurminah. (2017). Effect of Fermentation Method and Time on Chemical and Functional Characteristics of Orange Sweet Potato Flour. Jurnal Rekayasa Pangan dan Pertanian, 5(2), 20-21.

[6] Faridah DN, Kusumaningrum HD, Wulandari N and Indrasti D. (2006). Laboratory Analysis. Department of Food Science and Technology IPB, Bogor.

[7] AOAC. (2000). Official Methods of Analysis. Association of Official Analytical Chemist. Washington, United States of America.

[8] Aristya AL, Legowo AM and Albaarri AN. (2013). Total Acid, Total Yeast and Protein Profile of Goat Milk Kefir with Addition of Sugar Type and Concentration. Jurnal Pangan dan Gizi, 04(7), 39-48.

[9] Yuwono SS and Susanto T. Food Physical Testing. (1998). Faculty of Agricultural Technology, .Brawijaya University, Malang.

[10] Sudarmadji S, Haryono B and Suhardi. (1997). Analysis Procedures for Food and Agriculture Materials. Liberty, Yogyakarta.

[11] Aqil M and Effendi R. (2015). SPSS and SAS applications for experimental design. Absolute Media, Yogyakarta.

[12] Satmalee P, Surojanametakul V, Phomkaivorn N, Pantavee W and Yoshihashi, T. (2017). Removal of Soluble Proteins During Fermentation Process for Improving Textural Properties of Traditional Thai Rice Noodles, Kanom-jeen. Japan Agric. Res. Quarterly, 51(4), 327-331.

[13] Fessende JR and Fessenden SJ. (1990). Organic Chemistry. Third Edition.Erlangga, Jakarta.

[14] Ilowefah M, Chinma C, Bakar J, Ghazali H and Muhammad K. (2014). Brown rice flour as Functional Food Ingredient. Int. J. Env. Res. and Pub. Health, 3, 149-159.

[15] Saigusa N, Terahara N and Ohba. (2005). Evaluation of DPPH-Radical-Scavenging Activity and Antimutagenicity and Analysis of Anthocyanins in an Alcoholic Fermented Beverage Produced from Cooked or Raw Purple Fleshed Sweet Potato (Ipomoea Batatas) Roots. Food Sci. Tech. Res. 11(4), 390-394

[16] Armanto R and Nurasih AS. (2012). Study of Lactic Acid Bacteria Concentration and Fermentation Time in Making Cassava Acid Starch. J. Agritech. Faculty of Agricultural Technology, UGM. 28(3), 97-101.

[17] Aziza N, Al-Baarri A and Mulyani S. (2012). Effect of Fermentation Time on Alcohol Content, pH and Gas Production on the Bioethanol Fermentation Process of Whey with Pineapple Skin Substitution. Jurnal Aplikasi Teknologi Pangan. 1(2), 72-77.

[18] Buckle KA, Edward RA, Fleet GH and Wootton M. (2012). Ilmu Pangan. Indonesian Translate. University of Indonesia, Jakarta.

[19] Gandjar I. (2003). Tapai from Cassava and Cereals, In: Proceedings of the First International Symposium and Workshop on Insight In to the World of Indigenous Fermented Foods for Technology Development and Food Safety. Bangkok, Thailand, 152-157.

\section{How to cite this article}

Erika D.R, Priyanto G, Wijaya A, Santoso B and Pambayun R. (2019). Physicochemical properties of cassava (Manihot esculenta) tapai fermented by aeration. World Journal of Advanced Research and Reviews, 4(2), 112-116. 